\title{
Antileishmanial Activity of New Synthesized Schiff and Mannich (Morpholine) Base Compounds
}

\author{
Sentezlenmiş Schiffve Mannich (Morfolin) Bazı Bileşiklerinin \\ Antileishmanial Aktiviteleri \\ (1) Şahin Direkel ${ }^{1}$, (1) Yasemin Ünver ${ }^{2}$, (1) Cihangir Akdemir ${ }^{1}$ \\ ${ }^{1}$ Giresun University Faculty of Medicine, Department of Medical Microbiology, Giresun, Turkey \\ ${ }^{2}$ Karadeniz Technical University Faculty of Science, Department of Chemistry, Trabzon, Turkey
}

Cite this article as: Direkel Ş, Ünver Y, Akdemir C. Antileishmanial Activity of New Synthesized Schiff and Mannich (Morpholine) Base Compounds. Turkiye Parazitol Derg 2020;44(4):216-20.

\begin{abstract}
Objective: Leishmaniasis is an important parasitic disease in many countries, including ours. A variety of drugs are currently used for its treatment. However, certain side effects of these drugs, such as teratogenicity, hepatotoxicity and nephrotoxicity, have been reported in some patients. The goal of this research is to determine the antileishmanial effects of eight different previously synthesised compounds containing Schiff and Mannich bases (morpholine) against Leishmania infantum (L. infantum) promastigotes by the liquid microdilution method utilising alamarBlue.

Methods: Compounds containing Schiff bases (a-d) and both Schiff bases and morpholine rings (e-h) were tested. Compounds were diluted in the range of 20000-39 $\mu \mathrm{g} / \mathrm{mL}$. L. infantum promastigotes were added to the wells, which were then incubated at 27 ${ }^{\circ} \mathrm{C}$. The proliferation of Leishmania promastigotes was evaluated after 24,48 and 72 hours.

Results: In this study, compounds b, c and d (MIC values $156 \mu \mathrm{g} / \mathrm{mL}, 78 \mu \mathrm{g} / \mathrm{mL}$ and $156 \mu \mathrm{g} / \mathrm{mL}$ ) were found to be effective against $L$. infantum promastigotes, whereas compound $\mathrm{f}$ (MIC $>20000 \mu \mathrm{g} / \mathrm{mL}$ ) was found to be more the most ineffective compound.

Conclusion: These compounds may be potential drug candidates for the treatment of leishmaniasis. According to the results, there is a need for further studies, such as in vivo experimental animal models and ex vivo Leishmania amastigote macrophage cultures for compounds showing antileishmanial effects.
\end{abstract}

Keywords: Antileishmanial activity, leishmaniasis, schiff base, mannich (morpholine) base

ÖZ

Amaç: Leishmaniasis, ülkemizin de dahil olmak üzere birçok ülkede önemli bir parazitik hastalıktır. Hastalığın tedavisinde birbirinden farklı çok sayıda ilaç kullanılmaktadır. Ancak, bazı hastalarda bu ilaçlara bağlı ortaya çıkan teratojenite, hepatotoksisite ve nefrotoksisite gibi birtakım yan etkiler bildirilmiştir. Bu araştırmanın amacı, alamar mavisi içeren sıvı mikrodilüsyon yöntemi ile Leishmania infantum (L. infantum) promastigotlarına karşı önceden sentezlenmiş [Schiff ve Mannich (morpholine) baz içeren] sekiz farklı bileşiğin antileishmanial aktivitesinin belirlenmesidir.

Yöntemler: Çalışma kapsamında Schiff bazı içeren bileşikler (a-d) ile hem Schiff hem de morfolin halkası içeren bileşikler (eh) test edilmiştir. Sentezlenen bileşikler 20000-39 $\mu \mathrm{g} / \mathrm{mL}$ konsantrasyon aralığında olacak şekilde hazırlanmıştır. L. infantum promastigotları kuyucuklara ilave edilerek $27^{\circ} \mathrm{C}$ 'de inkübe edilmiştir. L. infantum promastigotlarının üremesi 24., 48 . ve 72. saatlerde değerlendirilmiştir.

Bulgular: Bu çalışmada; b, c ve d bileşiklerinin (MİK değeri $156 \mu \mathrm{g} / \mathrm{mL}, 78 \mu \mathrm{g} / \mathrm{mL}$ ve $156 \mu \mathrm{g} / \mathrm{mL}$ ) L. infantum promastigotlarına karşı daha etkili olduğu ve bileşik f'nin ise (MİK > $20000 \mu \mathrm{g} / \mathrm{mL}$ ) en etkisiz bileşik olduğu bulunmuştur.

Sonuç: Bu bileşikler leishmaniasisin tedavisindepotansiyel ilaç adayları olabilir. Bu çalışmanın sonuçları göstermektedir ki, in vitro antileishmanial etki gösteren bu bileşiklerin in vivo deneysel hayvan modelleri ve ex vivo Leishmania amastigot makrofaj kültürleri gibi daha ileri modellerle çalışılmasına ihtiyaç bulunmaktadır.

Anahtar Kelimeler: Antileishmanial aktivite, leishmaniasis, schiff baz, mannich (morpholine) baz

Received/Geliş Tarihi: 15.04.2020 Accepted/Kabul Tarihi: 28.07.2020

Address for Correspondence/Yazar Adresi: Şahin Direkel, Giresun University Faculty of Medicine, Department of Medical Microbiology, Giresun, Turkey

Phone/Tel: +90 4543101600 E-mail/E-Posta: sdirekel@yahoo.com ORCID ID: orcid.org/0000-0003-3368-0447 


\section{INTRODUCTION}

Leishmaniasis is considered as one of the important infectious parasitic diseases worldwide (1-3). This disease is common in many regions, including India, countries with a coast to the Mediterranean, Middle Eastern countries, and South American countries. This tropical disease, which is generally seen in developing countries and is ignored, emerges as a public health problem that results in an average of 2-4 million new cases and approximately 70000 deaths each year (4-7). Transmitted by the bite of certain sandflies, the parasite has different clinical pictures and shows epidemiological diversity $(1,8)$.

Sodium stibogluconate (Pentostam ${ }^{\circledR}$ ) and meglumine antimoniate (Glucantime ${ }^{\circledR}$ ) are generally used in the treatment of the disease; however, it is reported that the resistance against them is increasing (9-12). As an alternative to this treatment, different treatment protocols such as amphotericin B and lipid forms, paromomycin, pentamidine and miltefosine have been used $(1,13)$.

However, the effects of these drugs used in chemotherapy of leishmaniasis are very limited. Also, most of these drugs have serious side effects, especially nephrotoxic, hepatotoxic and teratogenic effects $(5,10,14)$. Unfortunately, there is not yet an effective vaccine to prevent the spread of the disease. Due to the side effects of the medications in the treatment and the resistance of the parasite to them, research aimed at developing new therapeutic tools to combat leishmaniasis continues to be a very important target today $(11,14,15)$. Different methods, especially microdilution methods, are used to determine antileishmanial activity. In these test applications, different colorimetric methods can be used to monitor the viability of the promastigote forms of the parasite and to determine if it continues to reproduce. It has been reported that alamar blue, which is used as an indicator dye in drug screening tests, has many advantages such as not affecting the reproduction of the parasite, environmentally friendly, cheap and simple to apply $(1,16)$.

It is stated that Schiff bases have many biological activities such as antiviral, antibacterial, antifungal, antimalarial, antiinflammatory, antiproliferative and antipyretic (17-20).

In this study, previously synthesized (17) eight new Schiff bases compounds (bearing thiophene, 1,2,4-triazolone, 1,3,4-oxadiazole, morpholine moieties) were tested for antileishmanial activity for Leishmania infantum (L. infantum).

\section{METHODS}

\section{Preparation of Test Compounds}

The compounds ( $\mathrm{a}-\mathrm{h})$ that have been investigated for in vitro antileishmanial activity have been previously synthesized by Ünver et al (17). The reaction Scheme is shown below.

\section{Synthesis of Compounds (a-d)}

0.01 mol [4-amino-2-(4-amino-5-mercapto-4H-1,2,4-triazol3-yl)methyl)-5-(thiophen-2-ylmethyl]-2,4-dihydro-3H-1,2,4triazol-3-one (1) and $0.02 \mathrm{~mol}$ aromatic aldehydes were heated in solvent-free oil bath at $160-170{ }^{\circ} \mathrm{C}$ for $2-3$ hours. After the temperature was reduced to room temperature, the resulting solid was recrystallized with a mixture of dimethyformamide (DMF) and water (1:5).

\section{Synthesis of Compounds (e-h)}

A mixture of formaldehyde $(0.02 \mathrm{~mol})$ and morpholine $(0.02$ mol) in DMF was added to solution of compounds (a-d) (0.001 $\mathrm{mol}$ ) in DMF. The final mixture was stirred at room temperature overnight. The precipitated solids were filtered, washed with water and recrystallized with methanol.

\section{Preparation of Compounds}

The eight synthesized new 1,2,4-triazole compounds containing Schiff and Mannich bases (morpholine) were weighed and dissolved in dimethylsulphoxyde $/ \mathrm{H}_{2} \mathrm{O}$ (10\%). They made homogeneous and membranes with $0.45 \mu \mathrm{m}$ pore diameter were filtered to sterilize (Millipore, USA) (18). Stock solutions of the compounds were prepared by adding Roswell Park Memorial Institute (RPMI)-1640 medium (R8758 Sigma Aldrich USA) [containing heat inactivated $10 \%$ Fetal Bovine Serum (FBS: F4135 Sigma-Aldrich USA)], no phenol red) to a concentration of $40000 \mu \mathrm{g} / \mathrm{mL}$.

\section{Preparation of Leishmania infantum Promastigotes}

For the antileishmanial activity test, the axenic standard MON183 L. infantum promastigotes were produced in RPMI-1640 medium (containing 10\% FBS, 1\% Penicillin (P3032 SigmaAldrich USA) and Streptomycin (S9137 Sigma-Aldrich USA). Then, to wash promastigotes, $20 \mathrm{~mL}$ of promastigote was taken and transferred to sterile falcon tubes and centrifuged at $1.000 \mathrm{~g}$ for 10 minutes. After the supernatant was removed, $20 \mathrm{~mL}$ sterile phosphate buffered saline was added to the tubes and vortexed. This mixture was centrifuged in the same way and the washing process was completed by repeating the process three times. Finally, as previously described, the cell number was adjusted by adding RPMI-1640 medium using a hemocytometer under the microscope so that the promastigote concentration was $2.5 \times 10^{5}$ cells/mL (1,21).

\section{In vitro Antileishmanial Activity Test}

The new compounds, well characterized by elemental analyses, 13C nuclear magnetic resonance (NMR), 1H NMR and infarared were tested for their antileishmanial activitiy against $L$. infantum
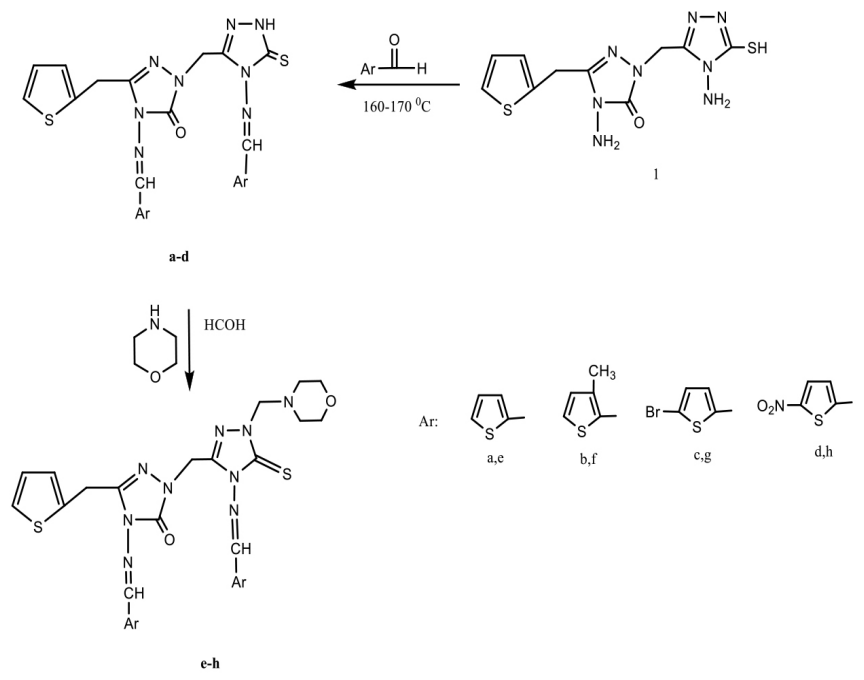

Scheme. Synthetic pathway for the preparation of compounds $(\mathrm{a}-\mathrm{h})$ 
promastigotes by liquid microdilution method with added alamar blue.

The assay was performed in 96-well flat bottom sterile microplates. Initially, $100 \mu \mathrm{L}$ from RPMI-1640 medium was added to all wells. Following, $100 \mu \mathrm{L}$ from stock solution of Schiff base compounds was added to the first well, and after thoroughly pipetting $100 \mu \mathrm{L}$ was taken and transferred into the second well. Thus, the compounds were diluted to $1 / 2$. Following the pipetting process, dilution from the second well to the tenth well was made to be between $20000 \mu \mathrm{g} / \mathrm{mL}$ and $39 \mu \mathrm{g} / \mathrm{mL}$. Finally $100 \mu \mathrm{L}$ of the standard $L$. infantum promastigotes suspension was added over the diluted compounds in the wells. In the study, $100 \mu \mathrm{L}$ of compound stock solution was added to well 11 for negative control and $100 \mu \mathrm{L}$ of standard parasite suspension to well 12 for positive control (1). This procedure was likewise performed for other Schiff base (b-d) compounds and schiff base and morpholine (e-h) compounds. The microplates were allowed to incubate for about 20 hours at $27^{\circ} \mathrm{C}$. After incubation, $20 \mu \mathrm{L}$ of indicator alamar blue (R7017: Resazurin sodium salt/Sigma-Aldrich USA) (0.1 mg/ $\mathrm{mL}$ ) was added to all wells and incubated again for approximately 4 hours. Evaluation were made after 24, 48 and 72 hours and the observed results were recorded (18) Amphotericin B was preferred as a control drug in this study. All tests on microplates were repeated twice.

Ethics committee approval has not been obtained due to working in standard Leishmania infantum isolate. No patient was used in the study. Patient approval has not been obtained due to the study of with synthesized compounds and standard parasite isolate.

\section{Statistical Analysis}

No statistical analysis has been made in this study.

\section{RESULTS}

The antileishmanial activity of schiff base compounds (a-d) and schiff base and mannich base compounds (e-h) were tested by using alamar blue added liquid microdilution method. If the original color of the indicator dye alamar blue changed from blue to pink, it showed that promastigotes continued to grow in the wells, but if there was no color change in the indicator dye, promastigote growth stopped (Figure 1). Color change was observed in all positive control wells, while no color change was observed in negative control wells. Table 1 provides the minimal inhibitory concentration (MIC) values of the compounds and amphotericin B.

Based on the results found, the substance with the highest activity was schiff base compound c, (MIC: $78 \mu \mathrm{g} / \mathrm{mL}$ ) then, compounds b and d (MIC: $156 \mu \mathrm{g} / \mathrm{mL}$ ), compounds a and h (MIC: $625 \mu \mathrm{g} / \mathrm{mL}$ ), compound e (MIC: $1250 \mu \mathrm{g} / \mathrm{mL}$ ) and compound g (MIC: $2500 \mu \mathrm{g} /$ $\mathrm{mL}$ ) (Table 1). Compound $\mathrm{f}$ was not found to have antileishmanial activity at all concentrations studied. The results found were much higher than the MIC value (MIC: $<39 \mu \mathrm{gL}$ ) of the control drug Amphotericin B. However, considering the side effects of current drugs used in the treatment, these compounds, which are found to have antileishmanial effects, can be considered as compounds that can contribute to drug development studies. In order for effective compounds to be drug candidates, it is necessary to determine the ex vivo effects of the compounds against the amastigote forms of Leishmania in macrophage cultures and to carry out control studies in in vivo experimental animals.

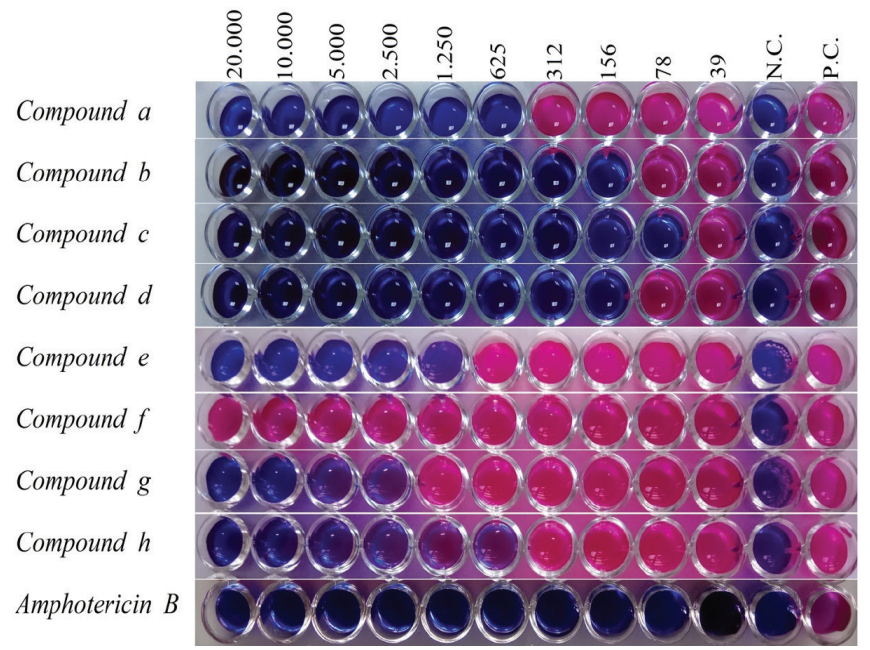

Figure 1. In vitro antileishmanial activities of substances against standard $L$. infantum promastigotes; line 1-4) schiff base derivatives (a-d), line 5-8) schiff base and mannich base derivatives (e-h), line 9) Amphotericin B. Dilution rates of substances were from $20000 \mu \mathrm{g} / \mathrm{mL}$ to $39 \mu \mathrm{g} / \mathrm{mL}$

N.C.: Negative control, P.C.: Positive control

Table 1. Minimal inhibitory concentrations of the compounds studied against standard $L$. infantum promastigotes

\begin{tabular}{|l|l|l|}
\hline & Compounds & MIC value $\boldsymbol{\mu g} / \mathbf{m L}$ \\
\hline 1 & Compound a & 625 \\
\hline 2 & Compound b & 156 \\
\hline 3 & Compound c & 78 \\
\hline 4 & Compound d & 156 \\
\hline 5 & Compound e & 1250 \\
\hline 6 & Compound $\mathrm{f}$ & $>20000$ \\
\hline 7 & Compound g & 2500 \\
\hline 8 & Compound h & 625 \\
\hline 9 & Amphotericin B & $<39$ \\
\hline MIC: Minimal inhibitory concentrations & \\
\hline
\end{tabular}

\section{DISCUSSION}

Among five common parasitic diseases worldwide, leishmaniasis is recognized as a major public health problem and affects approximately 12 million people (14). In the treatment of leishmaniasis, besides different antileishmanial drugs such as pentavalent antimony compounds, amphotericin B deoxycholate, miltefosine, paromomycin, citamaquin, azoles and pentamidine, applications such as thermotherapy and cryotherapy are also used (22). While the effectiveness of the five-valued antimony compounds used in its treatment has been reported to be over $90 \%$, it has also been reported that it may rarely cause local and systemic side effects such as myalgia, arthralgia, abdominal pain, hepatitis, pancreatitis and elevation in various laboratory values (23). Due to the development of resistance, as well as giving up the use of these compounds in treatment in India but it is still being used in the rest of the world (24). 
In our study, it was targeted to be detected the antileishmanial activity of eight different compounds in the structure of 1,2,4-triazole containing synthesized Schiff and Mannich (morpholine) base by using alamar blue microdilution method in axenic culture using $L$. infantum promastigotes.

Many compounds studied with the Alamar blue microdilution method were found to have in vitro antileishmanial activity and it was concluded that especially compounds b, c and d could be evaluated in terms of drug development studies due to their antiparasitic effect. The highest antileishmanial activity, were observed in compound $c$ against L. infantum (MON-183) with a MIC value of $78 \mu \mathrm{g} / \mathrm{mL}$. In the antileishmanial activity study, all compounds except compound $\mathrm{f}$ were found to be effective at different levels.

When resistance to antimony compounds develops, amphotericin $B$ is used intravenously or intramuscularly in the treatment of leishmaniasis (25). Since amphotericin B is widely spread throughout the body, it has side effects such as infusion reactions, nephrotoxicity, hypokalemia and myocarditis, and the patient is followed up for 4-5 weeks in hospital. To prevent the toxic effects of Amphotericin B used in treatment, various lipid formulations (liposomal amphotericin B) have been developed that can remain in these organs for a long time by rapidly increasing concentrations in the macrophages of organs such as the spleen and liver (22). The use of a drug that has few side effects and is effective in the treatment process is also important for the quality of life of the patient. There are studies on the identification and formulations of new molecules due to the toxic effects of anti-leishmanial drugs used in the treatment and the increased resistance to these drugs (5).

Mikus and Steverding (16) stated in a study that alamar blue was a useful colorimetric indicator in determining antileishmanial activity. In our study, alamar blue was used as indicator dye and likewise the alamar blue microdilution method has been found to be a simple, reliable and highly reproducible method in investigating anti-leishmanial drug activity.

Martin-Montes et al. (15) stated that, compared to the reference drug Glucantime, six out of twenty Mannich base derivatives showed 39 to 2.337 times higher selectivity index against amastigote forms. In the study evaluating the antileishmanial activities of new lawone Mannich bases derived from salicylaldehydes or nitrofurfura against L. major; They emphasized that four of the 15 compounds ( $5 a, 5 c, 6 a$ and $6 c$ ) were five times more active against promastigotes and four times more active against amastigotes (26).

Teran et al. (27) were evaluated 12 different Schiff bases against to L. mexicana promastigotes by 3-(4,5-Dimethylthiazol-2-yl)2,5-diphenyltetrazolium bromide assay. Some compounds were inactive or too weak, but they reported two compounds (5 and 3f) showed leishmanicidal activity in different level. New Schiff bases as resveratrol analogues compounds by Coimbra et al. (28) have been evaluated ex vivo against Leishmania species. They stated that all compounds tested against promastigotes of different leishmania species were effective at different concentrations (IC50 value in the range of 1.60 to $15.53 \mu \mathrm{g} \mathrm{mL}^{-1}$ ).

\section{CONCLUSION}

In order to use synthesized compounds as drug candidates; efficacy against amastigote forms of Leishmania in in vitro macrophage, which is thought to be necessary, and in vivo control studies in experimental animal are needs to be done. Since the compounds were newly synthesized, no study evaluating their antileishmanial activity was found. The compounds in our study can be regarded as a preliminary study in new drug development studies especially against $L$. infantum parasites and we can say that these compounds are promising.

\section{KNOWLEDGE}

Presented at $13^{\text {th }}$ Antimicrobic Chemotheraphy Days (6-8 April 2018).

\section{* Ethics}

Ethics Committee Approval: As this study conducted on standard Leishmania infantum isolate, there was no need to take ethical approval.

Informed Consent: No patients were used in the study. Because of working with synthesed compounds and standard parasit isolate, patient consent was not obtained.

Peer-review: Externally and internally peer-reviewed.

\section{* Authorship Contributions}

Concept: Ş.D., Y.Ü., Design: Ş.D., Y.Ü., C.A., Data Collection or Processing: Ş.D., Y.Ü., C.A., Analysis or Interpretation: Ş.D., Y.Ü., C.A., Literature Search: Ş.D., Y.Ü., Writing: Ş.D.

Conflict of Interest: The authors stated that there is no conflict of interest between them.

Financial Disclosure: The authors reported that they did not receive any financial support for this study.

\section{REFERENCES}

1. Süleymanoğlu N, Ünver Y, Ustabaş R, Direkel Ş, Alpaslan G. Antileishmanial activity study and theoretical calculations for 4-amino1,2,4-triazole derivatives. J Mol Struct 2017; 1144: 80-6.

2. Torres-Guerrero E, Quintanilla-Cedillo MR, Ruiz-Esmenjaud J, Arenas R. Leishmaniasis: a review. F1000Res 2017; 6: 750.

3. Markell EK, John DT, Krotoski VA. Markell and Voge's Medical Parasitology. Philadelphia: WB Saunders; 1999.p.340-5.

4. Tchokouaha Yamthe LR, Appiah-Opong R, Tsouh Fokou PV, Tsabang N, Fekam Boyom F, Nyarko AK, et al. Marine Algae as Source of Novel Antileishmanial Drugs: A Review. Drugs 2017; 15: 323.

5. Corral MJ, González E, Cuquerella M, Alunda JM. Improvement of 96well microplate assay for estimation of cell grow than dinhibition of leishmania with alamar blue. J Microbiol Methods 2013; 94: 111-6.

6. Doğan N, Bör O, Dinleyici EC, Töz SO, Özbel Y. Investigation of antileishmania seroprevalence by different serologic assays in children inhabiting in then or the western part of Turkey Mikrobiyol Bul 2008; 42: 103-11.

7. Armeli Minicante S, Michelet S, Bruno F, Castelli G, Vitale F, Sfriso A, et al. Bioactivity of phycocolloids against the mediterranean protozoan Leishmania infantum: An inceptive study. Sustainability 2016; 8: 1131.

8. Desjeux P. Leishmaniasis: current situation and new perspectives. Comp Immunol Microbiol Infect Dis 2004; 27: 305-18.

9. Dos Santos AO, Ueda-Nakamura T, Dias Filho BP, da Veiga Junior VF, Nakamura CV. Copaiba oil: An alternativeto development of new drugs against leishmaniasis. Evid Based Complement Alternat Med 2012; 2012: 898419.

10. Bekhit AA, Haimanot T, Hymete A. Evaluation of some $1 \mathrm{H}$-pyrazole derivatives as a dual acting antimalarial and anti-leishmanial agents. Pak J Pharm Sci 2014; 27: 1767-73. 
11. Özbilgin A, Çavuş İ, Yıldırım A, Kaya T, Ertabaklar H. Evaluation of in vitro and in vivo drug efficacy over leishmania tropica: a pilot study. Turkiye Parazitol Derg 2018; 42: 11-9.

12. Özbilgin A, Çavuş İ, Kaya T, Yıldırım A, Harman M. Pentavalent antimonial bileşiklere dirençli vahşi leishmania izolatlarının leishmaniasis tedavisinde kullanılan ilaçlara karşı in vitro dirençlerinin karşılaştııılması. Turkiye Parazitol Derg 2020; 44: 12-6.

13. Murray HW, Berman JD, Davies CR, Saravia NG. Advances in leishmaniasis. Lancet 2005; 366: 1561-77.

14. De Araújo MV, de Souza PS, de Queiroz AC, da Matta CB, Leite AB, da Silva $\mathrm{AE}$, et al. Synthesis, leishmanicidal activity and theoretical evaluations of a series of substituted bis-2-hydroxy-1,4-naphthoquinones. Molecules 2014; 19: 15180-95.

15. Martin-Montes A, Santivañez-Veliz M, Moreno-Viguri E, Martín-Escolano $\mathrm{R}$, Jiménez-Montes $C$, Lopez-Gonzalez $C$, et al. In vitro antileishmanial activity and iron superoxide dismutase inhibition of arylamine Mannich base derivatives. Parasitology 2017; 144: 1783-90.

16. Mikus J, Steverding D. A simple colorimetric method to screen drugcytotoxicity against leishmaniausing the dye alamar blue. Parasitol Int 2000; 48: 265-9.

17. Ünver Y, Deniz S, Çelik F, Akar Z, Küçük M, Sancak K. Synthesis of new 1,2,4-triazole compounds containing Schiff and Mannich bases (morpholine) with antioxidant and antimicrobial activities. J Enzyme Inhib Med Chem 2016; 31: 89-95.

18. Ustabaş R, Süleymanoğlu N, Ünver Y, Direkel Ş. 5-(4-Bromobenzyl)-4-(4(5-phenyl-1,3,4-oxadiazole-2-yl)phenyl)-2,4-dihydro-3H-1,2,4-triazole3-one: Synthesis, characterization, DFT study and antimicrobial activity. J Mol Struct 2020; 1214: 128217.

19. Bedia KK, Elcin O, Seda U, Fatma K, Nathaly S, Sevim R, et al. Synthesis and characterization of novel hydrazide-hydrazones and the study of their structure- antituberculosis activity. Eur J Med Chem 2006; 41: 1253-61.

20. Kritsanida M, Mouroutsou A, Marakos P, Pouli N, PapakonstantinouGaroufalias S, Pannecouque $C$, et al. Synthesis and antiviral activity evaluation of some new 6-substituted 3-(1-adamantyl)-1,2,4triazolo[3,4-b][1,3,4]thiadiazoles. Farmaco 2002; 57: 253-7.

21. Direkel Ş, Karaman Ü, Tezcan Ülger S, Utku S, Aslan G, Uysal M, et al. Investigation of Anti-leishmanial Activity of the Ten Different Hydrazone Derivatives. Kafkas Univ Vet Fak Derg 2016; 22: 519-24.

22. Sundar S, Chakravarty J. Leishmaniasis: an update of current pharmacotherapy. Expert Opin Pharmacother 2013; 14: 53-63.

23. Yeşilova Y, Turan E, Altın Sürücü H, Aksoy M, Özbilgin A. Sistemik lipozomal amfoterisin B tedavisine cevap veren kutanöz leishmaniasis olgusu. Turkiye Parazitol Derg 2015; 39: 63-5.

24. Croft SL, Barrett MP, Urbina JA. Chemotherapy of trypanosomiases and leishmaniasis. Trends Parasitol 2005; 21: 508-12.

25. Monge-Maillo B, Lopez-Velez R. Therapeutic options for visceral leishmaniasis. Drugs 2013; 73: 1863-88.

26. Al Nasr I, Jentzsch J, Winter I, Schobert R, Ersfeld K, Koko WS, et al. Antiparasitic activities of new lawsone Mannich bases. Arch Pharm (Weinheim) 2019; 352: e1900128.

27. Teran R, Guevara R, Mora J, Dobronski L, Barreiro-Costa O, Beske T, et al. Characterization of antimicrobial, antioxidant, and leishmanicidal activities of schiff base derivatives of 4-aminoantipyrine. Molecules 2019; 24: 2696.

28. Coimbra ES, Santos JA, Lima LL, Machado PA, Campos DL, Pavan FR, et al. Synthesis, antitubercular and leishmanicidal evaluation of resveratrol analogues. J Braz Chem Soc 2016; 27: 2161-9. 